\title{
상악동 진주종
}

대구가톨릭대학교 의과대학 이비인후과학교실

김보문 · 신승헌 · 예미경

\section{A Case of Cholesteatoma of Maxillary Sinus}

\author{
Bo-Mun Kim, MD, Seung-Heon Shin, MD, PhD and Mi-Kyung Ye, MD, PhD \\ Department of Otolaryngology-Head and Neck Surgery, School of Medicine, Catholic University of Daegu, Daegu, Korea
}

Cholesteatoma is common disease entity within the middle ear cavity but is rarely found in the paranasal sinuses, especially the maxillary sinus. We experienced a case of cholesteatoma of the maxillary sinus without history of previous trauma or operation. The patient was not improved by functional endoscopic sinus surgery. The mucosa of the maxillary sinus was removed through the Caldwell-Luc approach, and heavy saline irrigation was performed. After reoperation, the postoperative period was uneventful, and there was no sign of recurrence on endoscopic examination.

KEY WORDS: Cholesteatoma · Maxillary sinus.

\section{서 론}

진주종은 중이나 유양돌기에서는 흔한 질환이지만, 비부 비동에 생기는 경우는 극히 드물며, 전두동, 사골동, 상악동 순으로 발생빈도가 많다고 보고 되어있다. ${ }^{1)}$ 현재까지 영문 으로 보고 되어있는 상악동 진주종 증례는 40여개 가량이며, 한국어로 보고된 증례는 단 1 례만 있을 정도로 희귀한 질환 이다. ${ }^{2)}$

상악동 진주종의 증상은 비충만감이 가장 흔하며, 그 외 볼 부위의 통증 및 종창, 상악 부위의 팽창감, 재발성비루 등이 있다. ${ }^{3-5)}$ 드문 질환이면서 특징적인 임상양상이나 영상 소견 이 없기 때문에 수술 전에 진단은 매우 어렵다고 알려져 있 다. 최근 저자들은 상악동 진주종으로 진단된 1례를 경험하 여 문헌고찰과 함께 보고하는 바이다.

\section{증 례}

41세 남자 환자가 5년간 지속된 비충만감으로 일차의료기 관에서 약물 치료를 하였으나 호전이 없어 본원으로 내원하 였다. 화농성 비루 및 좌측 안와 주위의 통증, 안면통도 호소 하였으며 비내시경 검사에서 좌측 중비도에 비용종과 함께 다량의 화농성 비루가 관찰되었고 우측 비강은 특이소견 없 었다. 시력 및 시야 장애는 없었고 안구돌출도 관찰되지 않 았다. 부비동 및 안면부의 외상이나 수술 등의 과거력은 없었 고 치아 상태도 양호하였다. 컴퓨터 단층촬영에서 좌측 중비 도, 상악동, 전사골동에 연조직음영이 관찰되었다(Fig. 1). 좌 측 비용종성 만성 부비동염 혹은 진균성부비동염 의심 하에 부비동 내시경 수술을 시행하였다.

국소마취 하에 중비도의 비용종을 제거하고 상악동 자연 구를 확장한 후 상악동 내부를 관찰한 결과 진균구는 보이지 


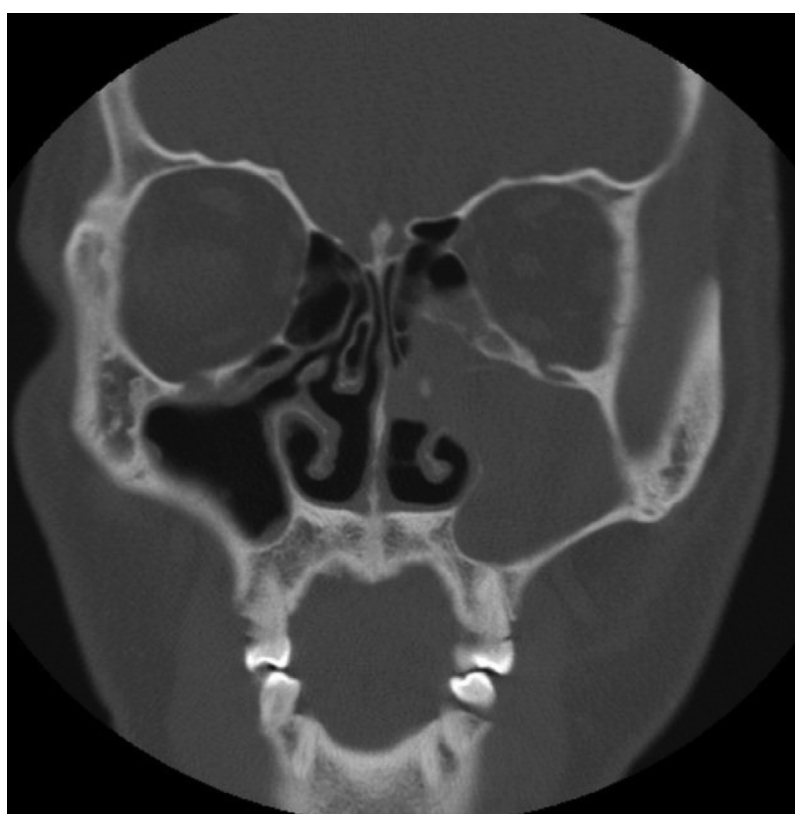

Fig. 1. Preoperative PNS CT showing non-homogeneous soft tissue density in the left maxillary sinus without bony remodeling.

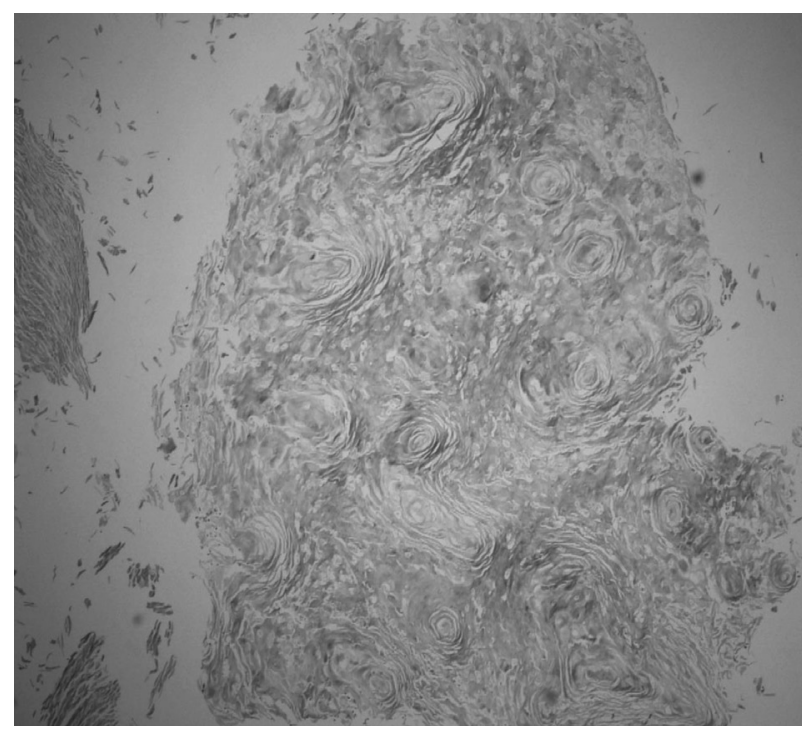

Fig. 2. Histopathological examination of specimen from maxillary sinus; Keratinous material (Hematoxylin and Eosin $\times 40$ ).

않았고 악취가 나는 백색의 물질이 가득 차 있는 것을 볼 수 있었다. 이는 만성부비동염에서 종종 관찰되는 농축된 분비 물 덩어리보다는 색깔이 훨씬 더 하얗고 밀가루같이 고운 입 자의 형태를 보였다. 상악동 내 물질을 채취하여 조직검사를 의뢰하고 다량의 식염수로 상악동 내를 깨끗이 세척한 후 수 술을 마쳤다. 병리조직검사상 케라틴 물질로 판독되었으며, 임상 소견을 고려하여 상악동 진주종으로 진단하였다(Fig. 2).

수술 후 비충만감, 안면부 및 안구주위 통증이 호전되었다 가, 술 후 3 개월부터 악취가 나는 비루가 재발하였다. 비내

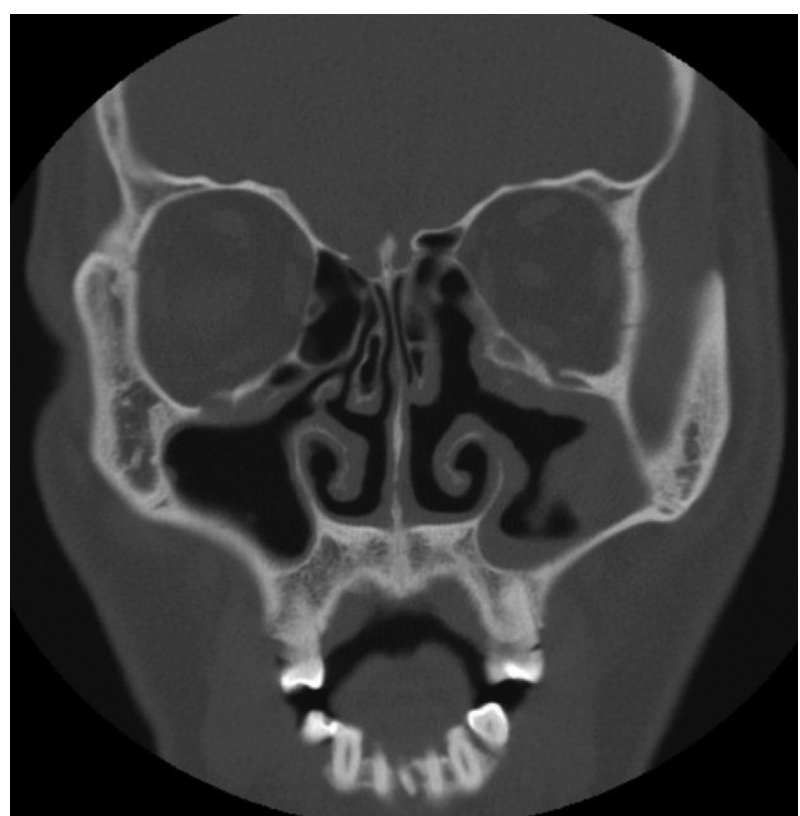

Fig. 3. PNS CT finding after 1 year of endoscopic sinus surgery showing mucosal thickening in left maxillary sinus without bony remodeling.

시경 검사에서 자연공은 열린 채로 유지되고 있었으나 상악 동 내부에 백색의 케라틴 물질이 관찰되어 외래에서 자연공 을 통한 상악동 세척을 시행하고 항생제를 처방하였다. 보존 적 치료에도 증상이 호전되지 않아서 상악동 근치수술을 권 유하였지만, 환자의 개인 사정으로 수술 받기를 거부하고 보 존적 치료를 더 해보기를 원하였다. 진주종에 의한 골미란이 나 안구 합병증 등을 파악하기 위해 정기적인 외래 진료를 하 였으며, 술 후 1년째 컴퓨터 단층 촬영을 시행하였고, 골 파 괴 소견이나 안구 합병증, 두개 내 합병증 등은 관찰되지 않 았다(Fig. 3).

그 후 환자의 개인 사정으로 외래 추적 관찰이 중단되었 다가 술 후 3 년째 수개월간 지속된 좌측 관골 부위의 통증으 로 내원하였고, 비내시경검사에서 좌측 상악동 개구부에 백 색의 케라틴 물질이 다량 관찰되었다(Fig. 4). 컴퓨터 단층 촬영에서 골 파괴 소견은 보이지 않았으나 이전 추적 검사 보다 악화된 좌측 상악동 전체를 채우는 연조직 음영 소견 관 찰되어(Fig. 5) 상악동 근치수술을 하기로 결정하였다.

수술은 전신마취 하에 부비동 내시경 수술 및 Caldwell$\mathrm{Luc}$ 수술을 시행하였다. 중비도의 비용종 및 염증 조직을 제 거하고, Caldwell-Luc 접근법으로 좌측 상악동을 관찰한 결 과 상악동 내 악취가 심한 흰색 물질이 가득 차 있었고 모든 점막이 편평상피로 대치되어 있는 것을 볼 수 있었다. 이들 을 깨끗이 제거하고 생리식염수로 여러 번 세척한 후 자연공 을 좀 더 확장 시킨 후 수술을 마쳤다. 최종 조직검사에서 케 


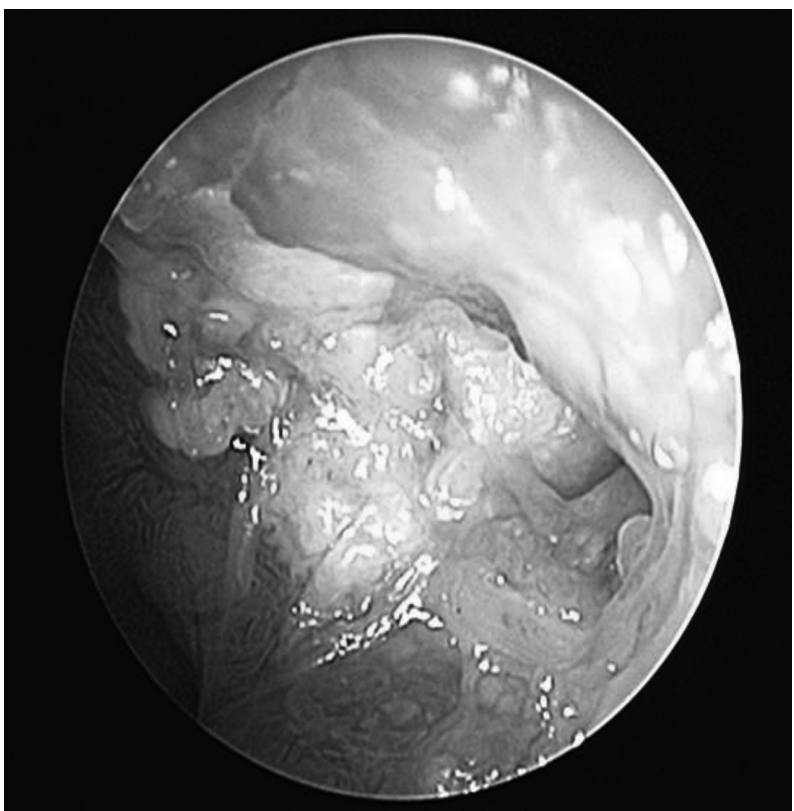

Fig. 4. Endoscopic finding of left maxillary sinus opening showing whitish keratin material.

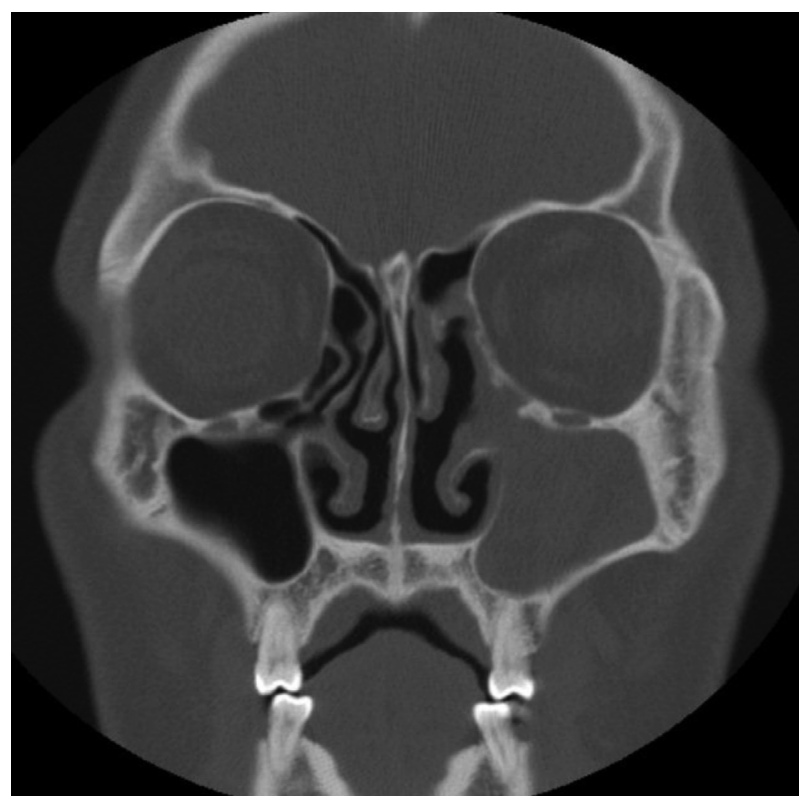

Fig. 5. PNS CT finding after 3 years of endoscopic sinus surgery showing worsened soft tissue density in maxillary sinus without bony remodeling.

라틴이 동반된 양성 편평상피 조직으로 상악동 진주종에 부 합되는 소견이었다(Fig. 6). 수술 후 통증 및 비강 내 악취가 호전되었으며, 외래 추적관찰 중 재발 등 특이소견은 없었다.

\section{고 찰}

비부비동에 발생한 진주종은 매우 드물며, 수술 전에 임상

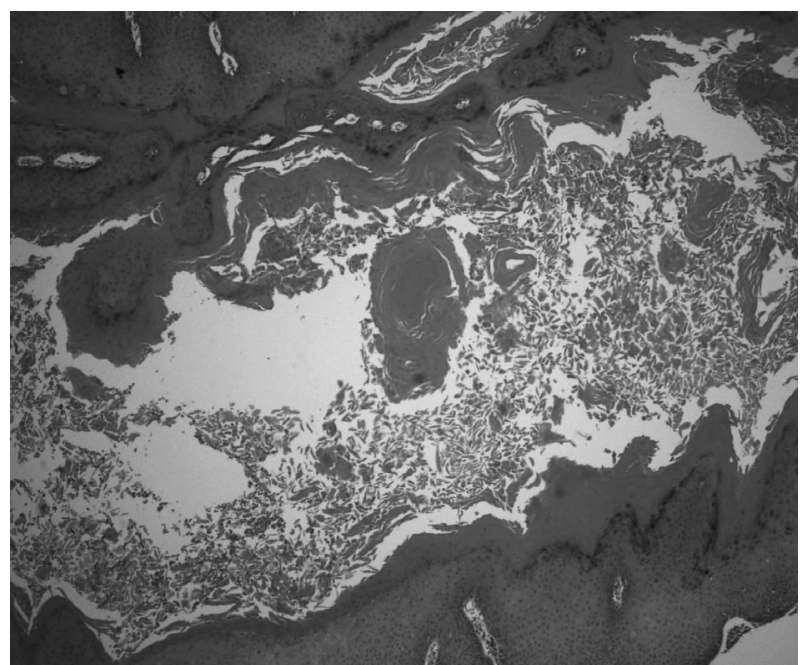

Fig. 6. Histopathological finding of maxillary sinus mucosa; fully differentiated, stratified squamous epithelium with lamellar sheets of keratin materials on connective tissue infiltrated with inflammatory cell (Hematoxylin and Eosin $\times 40$ ).

이나 영상소견만으로는 진단이 어렵고 수술 후 조직학적 진 단으로 확진이 이루어진다고 알려져 있다. 진주종은 완전히 분화된 중층편평상피와 염증 세포가 침투된 결체조직 위에 케라틴 물질이 층상 구조를 이루는 소견을 보인다. ${ }^{13-5)}$

이런 병리학적 특징으로 인하여 진주종(Cholesteatoma) 이라는 명칭보다는 각화종(Keratoma)으로 명명되어야 한다 고 주장된다.) 문헌 고찰 상 치료로는 병변의 완전한 제거를 위해 Caldwell- Luc 수술이 주로 시행되었고 ${ }^{2445)}$ 내시경적 으로 완전절제가 가능한 위치인 경우 부비동 내시경 수술을 시행하였으며 ${ }^{38899)}$ 몇몇 증례에선 추가적으로 상악동절개술 (Antrostomy) 또한 시행하였다. ${ }^{28199)}$ 술 후 경과에 대해선 완 전절제 시행 후 재발된 증례는 없었다. ${ }^{2-58899)}$

본 증례에서는 첫 수술에서 기능적 부비동 내시경수술 시 행하면서 백색의 케라틴 물질을 제거하였으나 상악동 점막 은 보존 하였다. 그 후 악취 및 통증 등의 증상이 재발하여 Caldwell-Luc 접근법으로 재수술을 시행하였으며, 상악동 의 염증성 조직 및 케라틴 물질, 편평상피화 된 상악동점막 을 전부 제거 하였으며, 그 후 증상이 호전되었다.

부비동진주종의 발생 기전에 대해서는 아직 정확하게 밝혀 져 있지 않지만, 4 가지의 이론적 가설이 알려져 있다. ${ }^{1224-699)}$

첫째, 태아 봉입설(fetal inclusion theory)로서 선천 상피 잔류물(congenital epithelial rest)은 태생기 5주경 2개의 외 배엽 면(ectodermal surface)의 분리가 불완전하게 일어나 신경고랑 폐쇄(neural groove closure)가 정상적으로 발생하 지 못해 상피 조직의 일부가 남아서 진주종이 발생된다는 가 설이다. 두 번째 가설은 착상설(implantation theory)로 외상 
이나 이전 수술 등에 의하여 상피 조직의 직접적인 착상에 의 해 생긴다는 것이다.

세 번째는 이주설(immigration theory)인데, 편평 상피세 포가 누공 등의 경로를 통하여 부비동 내로 이동하여 발생된 다는 가설이다.

마지막 네번째 가설은 화생설(metaplasia theory)이며, 정 상적인 부비강 내 상피가 만성 비부비동염으로 인하여 편평 상피로 화생을 일으키면서 진주종이 발생한다는 가설이다. 화생으로 인하여 생긴 편평 상피는 주로 비각화성(non-keratinized type)으로 진행되기에 가능성은 희박한 것으로 알 려져 있다. 네 가지 가설 중 태아 봉입설이 가장 가능성이 높 을 것으로 지지를 받고 있으며 수술이나 외상 등의 병력이 있는 경우 착상설로 병인을 설명하고 있다.

기존 보고된 증례들은 수술이나 외상의 병력, 미맹출 치아 등과 연관된 경우가 많았으나 본 증례에서는 이러한 병력이 없었다는 점이 특이하다. ${ }^{2}$ 또 첫 수술로 진단이 내려진 후 증상이 재발하였으나 환자의 재수술 거부로 인하여 약 3년 간 부비동진주종의 자연경과를 볼 수 있었던 점이 특이하다.

저자들은 극히 드문 상악동에 발생한 진주종을 치료한 경 험을 문헌 고찰과 함께 보고하는 바이다.
중심 단어 : 진주종 - 상악동.

\section{REFERENCES}

1) Hammami B, Mnejja A, Chakroun A, Achour I, Chakroun A, Charfeddine I, et al. Cholesteatoma of the frontal sinus. Eur Ann Otorhinolaryngol Head Neck Dis 2010;127:213-6.

2) Park SH, Baek SH, Song TH, Cha YJ. Cholesteatoma of the maxillary sinus. Korean J Otorhinolaryngol-Head Neck Surg 1999;4:522-5.

3) Puttamadaiah GM, Vijayashree MS, Viswanatha BO, Kaur JA. Cholesteatoma of maxillary sinus mimicking malignancy. Research in Otolaryngology 2014;3(4):57-9.

4) Min HJ, Shin JH, Kim KS. Cholesteatoma of maxillary sinus: What is the best surgical approach? J Craniofac Surg 2016;27:963-6.

5) Viswanatha B, Nayah L, Karthik S. Cholesteatoma of the maxillary sinus. Ear Nose Throat J 2007;86:351-3.

6) Hansen S, Sorensen CH, Stage J, Mouritzen A, Cayé-Thomasen P. Massive cholesteatoma of the frontal sinus: case report and review of the literature. Auris Nasus Larynx 2007;354:387-92.

7) Hopp ML, Montgomery WW. Primary and secondary keratomas of the frontal sinus. Laryngoscope 1984;94:628-32.

8) Viswanatha BO, Nayak KR, Karthik SH. Cholesteatoma of the maxillary sinus. Ear Nose Throat J 2007;86:351-3.

9) Lee JM, Ryu NG, Choi IS. A case of maxillary sinus cholesteatoma originating from the retromaxillary sinus wall. Int J Otolaryngol 2015; 4:325-8. 